\title{
Recenzja książki Miła Kwapiszewska, kukasz Moniuszko, Jacek Raniszewski, 2018, Aborcja w polskich sporach społeczno-prawnych lat 1919-1997, Wydawnictwo Avalon, Kraków
}

\author{
Maciej Stria \\ Wyższa Szkoła Gospodarki w Bydgoszczy \\ ul. Garbary 2, 85-229 Bydgoszcz \\ mstria1@wp.pl•ORCID: 0000-0002-3357-9405
}

\begin{abstract}
Aborcja jest problemem szeroko dyskutowanym w kręgach filozofów, teologów, prawników, psychologów, a także poza obszarem akademickim, zapewne dlatego też powstają coraz to nowsze publikacje z tego zakresu. Bez wątpienia jest to temat budzący spore kontrowersje moralne, niezależnie od prezentowanego przez dane środowisko stanowiska. Zasadnicze wydaje się pytanie: co stanowi o fakcie bycia człowiekiem. Pytanie to jest na tyle istotne, że nawet gotowa odpowiedź, znajdująca się w przepisach prawa, budzi wiele kontrowersji. Próbą rozwiązania tego problemu ma być prezentowana książka
\end{abstract} autorstwa trojga nauczycieli akademickich.

Miła Kwapiszewska jest genetykiem i filozofem skupiającym się w pracy naukowej na historii zagadnień bioetycznych. Prowadzi zajęcia w Państwowej Wyższej Szkole Zawodowej w Pile. Łukasz Moniuszko jest związany naukowo z Wyższą Szkołą Gospodarki w Bydgoszczy, gdzie prowadzi zajęcia z zakresu nauk społecznych, prawnych i humanistycznych. Jego zainteresowania naukowe skupiają się wokół teorii i filozofii prawa oraz analizie społecznie doniosłych pojęć prawnych, takich jak sprawiedliwość i wolność. Jacek Raniszewski jest lekarzem, absolwentem Wydziału Wojskowo-Lekarskiego Uniwersytetu Medycznego w Łodzi. Jego zainteresowania badawcze to zaburzenia narządów ruchu.

Formalnie publikację podzielono na pięć zasadniczych części poprzedzonych krótkim wstępem. Książka została opracowana w klasycznym ujęciu od ogółu do szczegółu. Już jednak na wstępie należy wskazać, że nie rozpoczyna ona dyskusji od wskazanego w tytule roku 1919. Właściwą polemikę otwiera bowiem rys filozoficzny, teologiczny i społeczny w odniesieniu do płodu ludzkiego, dodatkowo opis ten został podzielony na koncepcje niechrześcijańskie i chrześcijańskie. Autorzy zaniechali jednak próby wskazania wspólnego kulturowego mianownika tych spuścizn.

Jak wskazuje tytuł prezentowanej książki, głównym problemem naukowym jest ukazanie sporów społecznych i prawnych dotyczących zjawiska aborcji na przestrzeni określonego czasu. W słowie wstępnym autorzy zaznaczają, że analizowany okres nie kończy się w 1997 r. Obecnie obowiązujący kodeks karny jest przepisem z tego właśnie 
roku, lecz obowiązuje on cały czas. Zabieg ten wydaje się być niewłaściwy, gdyż może mylić czytelnika i sugerować historyczny charakter publikacji, a już na początku należy zaznaczyć, że lektura jedynie pośrednio ukazuje historię prawną problemu aborcji.

Na uwagę zasługuje staranna próba ukazania podwójnych standardów przy określaniu pojęcia „człowieczeństwo” - tak w naukach humanistycznych, jak i prawnych. Autorzy słusznie zauważają, że człowieczeństwo to atrybut, a nie formalne określenie istoty ludzkiej. Postulując swoje stanowisko, sięgają również do definicji prawnych, ukazując ich braki, a czasem wręcz wzajemne zaprzeczenia poszczególnych norm na tym samym poziomie obowiązywania przepisów prawnych. Ponadto, w tej części wywodu można zauważyć odwołania do prawa natury. Nic jednak nie wskazuje na to, czy należy je pojmować jako naukę prawną, czy jako gałąź filozofii, co ma kluczowe znaczenie dla podjętej dyskusji. Wszak prawo natury - postrzegane z punktu widzenia jurysprudencji posiada inne cechy niż koncepcje cechujące się tym samym punktem wyjścia, ale analizowane przez humanistów.

Właściwa część pracy, deklarowana w tytule, rozpoczyna się w trzecim jej fragmencie, który analizuje moralny kształt polskiej polityki aborcyjnej w latach 1919-1993. Autorzy słusznie zauważają, że „brak kraju na mapie świata przyniósł również zaległości w aspekcie prawnym" (s. 71). Ten problem widać przy analizie zagadnienia aborcji. Stąd zapewne obowiązywanie w latach 1919-1921 przepisów przejściowych na terenach odrodzonej Polski, które jednak pozostawiały duże pole do nadinterpretacji. Niestety, w tym aspekcie autorzy pozostawili wiele urwanych myśli, niedokończonych, jak choćby stwierdzenie, że „[...] Sekcja Prawa Karnego zaproponowała, by aborcja była przestępstwem śmiertelnym" (s. 72). Lektura nie podaje jednoznacznie, kiedy i czy propozycja ta została wprowadzona w życie. Na uwage zasługuje również ukazanie woli społecznej $\mathrm{w}$ tworzeniu i nowelizowaniu prawa. Jedną z opisanych propozycji ówczesnych władz miała być aborcja na życzenie, która za przesłankę obrała złą sytuację ekonomiczną kobiety ciężarnej, jednak pod naciskiem społecznym pomysł ten upadł.

Deklarowany w tytule rozdziału okres należy uznać za opracowany zadowalająco. Autorzy sięgnęli do wielu przepisów z omawianego okresu, analizując wręcz poszczególne zwroty (pojęcia), poddając je naukowej krytyce i ukazując błędy formalne. Nie umknął im również fakt, że wiele $\mathrm{z}$ powszechnie obowiązujących norm prawnych w tamtym okresie tworzonych było na kanwie kulturowej Związku Radzieckiego. Brakuje jednak w książce analizy, w jakim stopniu i w jakich obszarach stanowienia kultura miała wpływ na moralne aspekty prawa, w tym problem usunięcia płodu ludzkiego.

Autorzy zwrócili uwagę, że w 1919 r. nie utworzono nowych przepisów z powodu zmian ustrojowo-politycznych, a sytuacja ta powtórzyła się po 1989 r. Pierwszy przepis prawny dotyczący aborcji został wprowadzony dopiero w 1993 r. ustawą o planowaniu rodziny i dopuszczalności przerywania ciąży. Jest to refleksja otwierająca ostatnią, najbardziej szczegółową część opracowania. Autorzy analizują wspomnianą ustawę o dopuszczalności przerywania ciąży, starając się ukazać braki w jej zapisach. Dla przykładu, przepis ten wskazuje na możliwości usunięcia ciąży, ale nie wskazuje na bariery temu towarzyszące, wynikajacce $\mathrm{z}$ innych przepisów.

W części tej czytelnik znajdzie szeroki wachlarz dylematów etycznych towarzyszących podejmowanym decyzjom moralnym opartym na prawie. Wskazane zostały również sytuacje krańcowe, bazujące na hipotezach, np.: co w przypadku, gdy zabieg usunięcia ciąży jest legalny, a podmiot wykonujący wydobędzie żywy płód; czy lekarz może powołać się na klauzulę sumienia i odmówić wykonania aborcji, która jest konieczna dla ratowania życia kobiety ciężarnej. Obraz uzupełnia opinia społeczna na temat prezentowanego zjawiska. 
W książce można znaleźć rozdział ujmujący płód ludzki w prawie międzynarodowym, ale wydaje się, że nie wnosi on do dyskusji istotnych informacji. Z powodzeniem mógłby stanowić część innego rozdziału.

Ogólne wrażenie z lektury może być zadowalające, trudno bowiem doszukać się na liście tytułów dotyczących aborcji z analizą zawierającą elementy humanistyczno-społeczne, medyczne i prawne. Interesującym elementem mogą być eksperymenty myślowe, mające zmusić czytelnika do autorefleksji. Brakuje jednak płynnego przejścia od antyku do okresów późniejszych. Autorzy rozpoczynają swoją historię w starożytności, by niemal nagle przenieść czytelnika do XX w. Najwięcej problemów sprawiła autorom współczesność i usystematyzowanie postulatów i oczekiwań społecznych. Inną sprawą jest to, że z zaprezentowanych w książce badań wynika, iż większość ludzi nie wie, jaka kara grozi obecnie kobiecie za poddanie się aborcji. Wszak nie grozi żadna. W tym przypadku uzupełnieniem braku sankcji karnej mogłyby być konsekwencje społeczne, ale nie ujęto ich w recenzowanym opracowaniu. W trakcie lektury odnosi się wrażenie, że autorzy nieco na siłę szukali powiązania problemu z ustawą zasadniczą.

Prezentowanej monografii daleko do opracowania historycznego, filozoficznego, socjologicznego czy prawnego. Najbezpieczniej jest ją nazwać opracowaniem humanistycznym, w które wpisuje się wiele współczesnych nauk, ale nie na tyle mocno, by do którejś z tych dziedzin książkę tę przyporządkować. Tytuł, szczególnie w kwestii dat, również może być mylący. 